\title{
Chloropalladated propargyl amine: a highly efficient phosphine-free catalyst precursor for the Heck reaction
}

\author{
Crestina S. Consorti, Mara L. Zanini, Sheila Leal, Gunter Ebeling and \\ Jaïrton Dupont* \\ Laboratory of Molecular Catalysis, IQ,- UFRGS. Av. Bento Gonçalves, 9500 Porto Alegre, 91501-970 RS \\ Brazil.E-maildupont@iq.ufrgs.br
}

\section{General Methods}

All catalytic reactions were carried out under argon or nitrogen atmosphere in oven dried resealable Schlenk tube. All substrates were purchased from Acros and used without further purification. Butyl acrylate and styrene were purchased from Aldrich. Styrene was distilled prior to use from $\mathrm{CaH}_{2}$ under argon. Dimethylacetamide was degassed and stored over molecular sieves. NMR spectra were recorded on a Varian Inova $300 \mathrm{MHz}$ spectrometer. Infrared spectra were performed in a Bomem B-102 spectrometer. Mass spectra were obtained on a GC/MS Shimadzu QP-5050 (EI, 70eV). Gas chromatography analyses were performed on a Hewlett-Packard-5890 Gas Chromatograph with a FID detector and 30 meter DB17 capillary column.

\section{Synthesis of 3-(dimethylamino)-1-phenyl-1-propyne}

Dimethylamine (40\% aqueous solution, $91 \mathrm{~mL}, 0.72 \mathrm{~mol}$ ) was added to a stirred mixture of phenylacetylene $(49.0 \mathrm{~g}, 0.48 \mathrm{~mol})$, paraformaldehyde $(30.0 \mathrm{~g} ; 0.53 \mathrm{~mol})$ and cuprous iodide $(0.45 \mathrm{~g})$ in $250 \mathrm{~mL}$ dioxane. The reaction mixture was refluxed for $4 \mathrm{~h}$ and the solvent was removed under reduced pressure. Distillation of the residue afforded a colorless liquid of boiling point $114^{\circ} \mathrm{C} / 5 \mathrm{mmHg}(71.8 \mathrm{~g}, 94 \%$ yield $)$. GC-

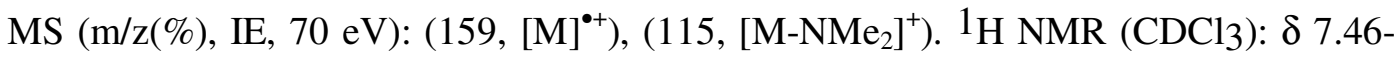
$7.38\left(\mathrm{~m}, 2 \mathrm{H}, \mathrm{H}\right.$ aromatic); 7.33-7.23 (m, 3H, $\mathrm{H}$ aromatic); $3.45\left(\mathrm{~s}, 2 \mathrm{H}, \mathrm{CH}_{2} \mathrm{~N}\right) ; 2.35(\mathrm{~s}$, 
$\left.6 \mathrm{H}, \mathrm{NMe}_{2}\right) .{ }^{13} \mathrm{C}\left\{{ }^{1} \mathrm{H}\right\} \mathrm{NMR}\left(\mathrm{CDCl}_{3}\right): \delta 132.1,128.5,128.1(\mathrm{CH}$ aromatic $) ; 124.1(\mathrm{C}$ aromatic); 85.9, $85.1(\mathrm{C} \equiv \mathrm{C}) ; 49.8\left(\mathrm{CH}_{2} \mathrm{~N}\right) ; 44.4\left(\mathrm{NMe}_{2}\right)$.

\section{Synthesis of palladacycle $\left\{\mathrm{Pd}\left[\mathrm{k}^{1}-C, \mathrm{k}^{1}-N-\mathrm{C}=\left(\mathrm{C}_{6} \mathrm{H}_{5}\right) \mathrm{C}(\mathrm{Cl}) \mathrm{CH}_{2} \mathrm{NMe}_{2}\right](\mu-\mathrm{Cl})\right\}_{2} 1$}

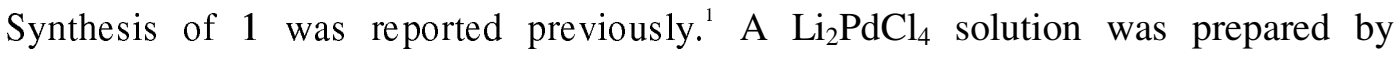
dissolving $\mathrm{PdCl}_{2}(0.745 \mathrm{~g}, 4.20 \mathrm{mmol})$ and $\mathrm{LiCl}(0.45 \mathrm{~g}, 10.5 \mathrm{mmol})$ in hot methanol (15 mL). After dissolution of the solids, the solution was cooled to room temperature and 3-(dimethylamino)-1-phenyl-1-propyne $(0.80 \mathrm{~g}, 5.00 \mathrm{mmol})$ was added. The resulting suspension was stirred for $1 \mathrm{~h}$. Filtration and washing of the resulting solid with cold $\mathrm{MeOH}$ and drying under reduced pressure afforded a yellow solid of melting point $172-5{ }^{\circ} \mathrm{C}$ (dec.) (1.24 g, 88\% yield). Anal.: $\left(\mathrm{C}_{11} \mathrm{H}_{13} \mathrm{Cl}_{2} \mathrm{NPd}\right)_{2}(673.11) \mathrm{Calc.:} \mathrm{C}$, 39.26; H, 3.89; N, 4.16. Found: C, 39.40; H, 3.99; N, 4.15. IR (KBr, $\left.\mathrm{cm}^{-1}\right): 1600\left(v_{\mathrm{C}=\mathrm{C}}\right)$. ${ }^{1} \mathrm{H}$ NMR $\left(\mathrm{CDCl}_{3}\right): \delta 7.35-6.90\left(\mathrm{~m}, 10 \mathrm{H}, \mathrm{H}\right.$ aromatic); $3.61\left(\mathrm{~s}, 2 \mathrm{H}, \mathrm{CH}_{2} \mathrm{~N}\right) ; 3.59(\mathrm{~s}, 2 \mathrm{H}$, $\left.\mathrm{CH}_{2} \mathrm{~N}\right) ; 2.88\left(\mathrm{~s}, 6 \mathrm{H}, \mathrm{NMe}_{2}\right) ; 2.77\left(\mathrm{~s}, 6 \mathrm{H}, \mathrm{NMe}_{2}\right) .{ }^{1} \mathrm{H} \mathrm{NMR}\left(\mathrm{CDCl}_{3}+\mathrm{Py}-\mathrm{d}_{5}\right): \delta$ 6.92-6.75 (m, 5H, H aromatic); $3.67\left(\mathrm{~s}, 2 \mathrm{H}, \mathrm{CH}_{2} \mathrm{~N}\right) ; 3.01\left(\mathrm{~s}, 6 \mathrm{H}, \mathrm{NMe}_{2}\right) .{ }^{13} \mathrm{C}\left\{{ }^{1} \mathrm{H}\right\} \mathrm{NMR}\left(\mathrm{CDCl}_{3}\right)$ : $\delta 142.9,142.7,141.9,141.7,116.1,115.7$ ( $\mathrm{C}$ aromatic and $\mathrm{C}=\mathrm{C}) ; 128.1,127.7,127.5$, 127.4, 125.9, $125.8\left(\mathrm{CH}\right.$ aromatic); 74.6, $74.3\left(\mathrm{CH}_{2} \mathrm{~N}\right)$; 53.2, $52.9\left(\mathrm{NMe}_{2}\right)$.

\section{Typical experiment for the Heck reaction}

A $10 \mathrm{~mL}$ resealable schlenk flask was evacuated and back-filled with argon and charged with sodium acetate $(1.4 \mathrm{mmol}, 112 \mathrm{mg})$ and tetrabutylammonium bromide $(0,2 \mathrm{mmol}$, $64 \mathrm{mg}$ ). The flask was then evacuated and back-filled with argon and than were added dimethylacetamide ( $5 \mathrm{~mL}$ ), iodobenzene (1mmol, $112 \mu 1,204 \mathrm{mg})$, butyl acrylate $(1.2$ mmol, $172 \mu \mathrm{l}$ ) and methyl benzoate as internal standard (35mg). After the addition of

${ }^{1}$ Dupont, J.; Basso, N. R.; Meneghetti, M. R. and Konrath, R. A. Organometallics 1997, 16, 2386 -2391. Yukawa, T.; Tsutsumi, S. Inorg. Chem. 1968, 7, 1458. 
the palladacycle 1 in dimethylacetamide $\left(42 \mu \mathrm{l}\right.$ of a $2.4 \times 10^{-3} \mathrm{M}$ solution, $\left.10^{-3} \mathrm{mmol}\right)$ the reaction mixture was stirred at $50^{\circ} \mathrm{C}$ for $24 \mathrm{~h}$. GC analysis gave $100 \%$ yield in butyl trans-cinnamate. The solution was then allowed to cool to room temperature, taken up in $\mathrm{CH}_{2} \mathrm{Cl}_{2}(15 \mathrm{~mL})$ and washed with $10 \mathrm{wt} \%$ aqueous sodium hydroxide $(10 \mathrm{~mL})$, and then dried over $\mathrm{MgSO}_{4}$. After filtration, solvent was evaporated to give butyl transcinnamate $(150 \mathrm{mg}, 95 \%)$ estimated to be $>95 \%$ pure by ${ }^{1} \mathrm{H}$ NMR and GC. ${ }^{1} \mathrm{H}$ NMR $\left(300 \mathrm{MHz}, \mathrm{CDCl}_{3}\right) \delta 7.68(\mathrm{~d}, J=15.9 \mathrm{~Hz}, 1 \mathrm{H}, \mathrm{CH}$ olefinic), 7.60-7.35(m, 5H, CH aromatic), 6.44 (d, J=16 Hz, CH olefinic ), $1.46\left(\mathrm{~m}, 2 \mathrm{H}, \mathrm{CH}_{2}\right), 1.70\left(\mathrm{~m}, 2 \mathrm{H}, \mathrm{CH}_{2}\right), 4.21$ $\left(\mathrm{t}, 2 \mathrm{H}, \mathrm{CH}_{2}\right), 0,96$ (t, 3H, Me). ${ }^{13} \mathrm{C}\left\{{ }^{1} \mathrm{H}\right\} \mathrm{NMR}\left(\mathrm{CDCl}_{3}\right)$ : $\square 167.1$ (CO), 144.5, 134.4, 130.1, 128.8, 128.0, 118.3 (C aromatic and $\mathrm{CH}$ olefinic), $64.4\left(\mathrm{CH}_{2}\right), 30.8\left(\mathrm{CH}_{2}\right), 19.2$ $\left(\mathrm{CH}_{2}\right), 13,7(\mathrm{Me}) . \mathrm{IR}$ (neat, $\left.\mathrm{cm}^{-1}\right)$ 3061, 3030 ( $v \mathrm{CH}$ aromatic), 1713 ( $\left.v \mathrm{C}=\mathrm{O}\right), 1638$ ( $v$ $\mathrm{C}=\mathrm{C}) . \mathrm{GC}-\mathrm{MS}(\mathrm{m} / \mathrm{z}(\%), \mathrm{IE}, 70 \mathrm{eV}): 131$ (100, M + -OBu), 103 (58), 51(54), 204 (10, M $+), 77(44)$.

\section{Typical experiment for the Hammet competition reaction}

A 10mL resealable schlenk flask was evacuated and back-filled with argon and charged with sodium acetate $(1.4 \mathrm{mmol}, 112 \mathrm{mg})$ and tetrabutylammonium bromide $(0,2 \mathrm{mmol}$, $64 \mathrm{mg}$ ). The flask was then evacuated and back-filled with argon and than were added dimethylacetamide $(5 \mathrm{~mL})$, butyl acrylate $(10 \mathrm{mmol}, 1.5 \mathrm{~mL})$, methyl benzoate as internal standard (35mg) and $0.14 \mathrm{mmol}$ of the substrates: $\mathrm{C}_{6} \mathrm{H}_{5} \mathrm{Br}$, 4-MeOC $\mathrm{M}_{6} \mathrm{Br}$, 4$\mathrm{MeC}_{6} \mathrm{H}_{4} \mathrm{Br}$, 4- $\mathrm{ClC}_{6} \mathrm{H}_{4} \mathrm{Br}$, 4- $\mathrm{NCC}_{6} \mathrm{H}_{4} \mathrm{Br}$, 4- $\mathrm{MeCOC}{ }_{6} \mathrm{H}_{4} \mathrm{Br}$ and 4- $\mathrm{NO}_{2} \mathrm{C}_{6} \mathrm{H}_{4} \mathrm{Br}$. After the addition of the palladacycle 1 in dimethylacetamide $\left(42 \mu 1\right.$ of a $2.4 \times 10^{-5} \mathrm{M}$ solution) the reaction mixture was stirred at $150^{\circ} \mathrm{C}$. The reaction was monitored by GC and was stopped at maximum $30 \%$ conversition of the most reactive bromoarene (4$\mathrm{NO}_{2} \mathrm{C}_{6} \mathrm{H}_{4} \mathrm{Br}$ ). The same experiment was performing using separately the activated and deactivated bromo-arenes and the initial relative rates were used to plot Hammet correlation giving the same results.

\section{Hg Poisonig experiment}

Two identical Heck experiments consisting in butyl acrylate (1.2 mmol, $172 \mu \mathrm{l})$, iodobenzene ( $1 \mathrm{mmol}, 112 \mu \mathrm{l}), 5 \mathrm{~mL}$ of dimethylacetamide, sodium acetate $(1.4 \mathrm{mmol}$, $112 \mathrm{mg})$, tetrabutylammonium bromide $(0,2 \mathrm{mmol}, 64 \mathrm{mg})$ and palladacycle 1 in dimethylacetamide $\left(42 \mu \mathrm{l}\right.$ of a $2.4 \times 10^{-3} \mathrm{M}$ solution, $\left.\left.10^{-3} \mathrm{mmol}\right)\right]$ were stirred at $80^{\circ} \mathrm{C}$. 
Aliquots were taken from both reactions and analyzed by GC. After two hours, $\mathrm{Hg}(0.3$ $\mathrm{mmol}, 60 \mathrm{mg}$ ) was added to one reaction vessel. 